Volume 12

Issue 2 Images And Collective Violence:

Function, Use And Memory

Article 3

$10-2018$

\title{
Reflections on the Significance of Images in Genocide Studies: Some Methodological Considerations
}

Lior Zylberman

Universidad Nacional de Tres de Febrero

Vicente Sánchez-Biosca

Universitat de València

Follow this and additional works at: https://digitalcommons.usf.edu/gsp

\section{Recommended Citation}

Zylberman, Lior and Sánchez-Biosca, Vicente (2018) "Reflections on the Significance of Images in Genocide Studies: Some Methodological Considerations," Genocide Studies and Prevention: An International Journal: Vol. 12: Iss. 2: 1-17.

DOI:

https://doi.org/10.5038/1911-9933.12.2.1620

Available at: https://digitalcommons.usf.edu/gsp/vol12/iss2/3

This Articles is brought to you for free and open access by the Open Access Journals at Digital Commons @ University of South Florida. It has been accepted for inclusion in Genocide Studies and Prevention: An International Journal by an authorized editor of Digital Commons @ University of South Florida. For more information, please contact digitalcommons@usf.edu. 


\section{Reflections on the Significance of Images in Genocide Studies: Some Methodological Considerations}

\section{Acknowledgements}

This introduction was translated by Lucía Tejada. 


\section{Reflections on the Significance of Images in Genocide Studies: Some Methodological Considerations}

Social practices such as massacres, mass violence and the extermination of entire populations are not a historical novelty. Indeed, when Raphael Lemkin coined the term genocide in 1944 -after suggesting barbarity in 1933- he was but giving a new name to an old crime. ${ }^{1}$ Such phenomena have been witnessed by humanity since Ancient times and historians, as well as artists and writers, have utilized every tool at their disposal to find ways to depict them and impress upon their audience the impact they had. Insofar as these are extreme phenomena that challenge the very notion of our humanity, such events inevitably test as well the limits of representation. ${ }^{2}$ Eyewitness accounts, historical narrations, philosophical observations, and ethical considerations, and studies from a social disciplines such as psychology, psychiatry, criminology, sociology and anthropology, have all been plagued with the difficulty posed by the comprehension and representation of genocides. As far as the visual is concerned, there has never been a lack of images attempting to depict or describe mass violence. Visual representation however, a form of representation that is adept at inciting emotions and affections, for this very reason, creates the ever-present risk of devolving into fascination, to the perversions of the gaze (voyeurism, in particular) and befuddlement of the conscience. Furthermore, as is to be expected, the disparity between the various ways of understanding, narrating and visualizing genocide and mass violence has produced complex configurations, especially since technological advances in photography allowed the visual capture of scenes as they transpired, introducing a literal notion of imprint.

Although, as a field, genocide studies has always been characterized by its interdisciplinarity, the consolidation in the last few decades of visual studies, including film and media, as academic fields, has allowed for a far more rigorous analysis of images of genocides that rests upon formal and semantic expertise specific to audio-visual representation. Thus, it is no longer a matter of invoking images as illustrations or for reinforcing other claims, but rather of wondering in what ways they contribute both to the knowledge of events and to the transmission of memory, whether individual or collective (for a family, for small communities or even for the encyclopedic by rote memory of humanity). Incidentally, it is worthwhile to recall that this "pictorial turn" has implications for the constellation of disciplines within genocide studies. ${ }^{3}$ In light of this state of affairs, this special issue, the first to be published by Genocide Studies and Prevention, endeavors to undertake these challenges and to make a substantial contribution to this field, but with no intention to homogenize a landscape enriched by different and sometimes contradictory perspectives and approaches.

Another field that grew considerably at the same time as the aforementioned disciplines, especially from the 1990s onwards, has been that of memory studies. Within disciplines such as neuroscience, psychology, sociology and anthropology, memory, both social and individual, has become a main subject of analysis not only in regards to its workings, but also to its reproduction and preservation. This resurgence ${ }^{4}$ has brought with it new debates, particularly within the field of history as a result of the disputes on history and memory ${ }^{5}$, becoming as well a central subject of debate in genocide studies, particularly in the analysis of community, social or state forms of memory. In this context, the different approaches that incorporate visual studies, such

\footnotetext{
1 "The word is new, the crime ancient." Leo Kuper, Genocide: Its Political Use in the Twentieth Century (New Haven and London: Yale University Press, 1981), 11.

${ }^{2}$ José Emilio Burucúa and Nicolás Kwiatkowski, "Cómo sucedieron estas cosas." Representar masacres y genocidios (Buenos Aires: Katz, 2014).

${ }^{3}$ The pictorial turn, according to W. J. T. Mitchell, refers to a set of changes and transformations undergone by society, culture and the sciences, by which "images comprise a singular point of friction and disquiet which transversely intersects a great range of intellectual research fields across disciplines." W. J. T. Mitchell, Teoría de la imagen (Madrid: Akal, 2009), 21.

${ }^{4}$ This topic was a focal point of research in these disciplines in the 1920s.

${ }_{5}^{5}$ Pierre Nora, "Entre memoria e historia. La problemática de los lugares," in Pierre Nora en Les Lieux de mémoire (Montevideo: Trilce, 2008), 19-39.
} 
as those of James Young, ${ }^{6}$ Barbie Zelizer, ${ }^{7}$ Marianne Hirsch, ${ }^{8}$ or Alexandre Dauge-Roth, ${ }^{9}$ have explored the various modes of memory of the traumas produced by acts of mass violence. Our approach understands images as vectors of memory and imagination in line with the perspective of historian Henry Rousso. As such, we understand as vector of memory all objects and products, including visual productions, "whose objective is to understand the past and to give it a certain intelligibility." 10 In the same vein, Rousso elaborates that a variety of things can be vectors of memory, such as history, commemorations, survivor organizations, as well as artistic creations. Moreover, images can act as vectors of memory and imagination, since they are shaped by, and often reflect, historical and symbolic debates regarding genocides. Images thus, both confirm and contest the link between what's considered (in)visible and (un)speakable in each historical context, as they selectively crystallize memories, interpretations and perspectives on the past. ${ }^{11}$

\section{Image, Reality, Evidence}

As technical developments in photography and the dissemination of images advanced rapidly over the past century, ${ }^{12}$ a paradigm shift in the production and consumption of imagery took place that is still underway and has yet to be fully understood and theorized..$^{13}$ One major ramification of the invention of photography has been that the seeming visual reproduction of "reality" would ascribe specific functions to the image that modified notions of objectivity and imposes an effect of how we perceive reality (effet de reel) that carry with them significant consequences. In addition to this effect on conceptions of reality, advances in photographic technology have also deeply affected our relationship with time, since photographic images can now be produced contemporaneously, as events are happening. Consequently, image now operate as a form of testimony, which is regularly used to assess the accuracy of other forms of documentation (eyewitness accounts, documents, etc.). Often overlooked however, is the fact that photographic processes are, like all modes of reproduction and representation, imprecise and incomplete, thereby reproducing the same sorts of conflict and contention surrounding other forms of documentation. The expansion of the visual field with the advent of film brought with it both further possibilities and consequences. Unlike photography, video production processes allow the capture of actions in movement (that is, throughout a fragment of real time). Technological advancements now also facilitate the synchronous capture of sound and colour, allowing producers to further blur the distinction between representation and reality. Moreover, very early on, photography and film became central to propaganda efforts and news dissemination. As such, it is hardly surprising that, at least from the coverage of the First World War onwards, these mediums would be added to the broad arsenal of equipment used to capture, make a record of, denounce, and, ultimately, represent various forms of mass violence.

There are three singular episodes which allow for the analysis of these early uses of both photography and film before the latter was capable of capturing synchronous sound. ${ }^{14}$ In the early twentieth century, photography was central to the denunciation of atrocities perpetrated by King Leopold II of Belgium in the Congo Free State ${ }^{15}$ referred to as "crimes against humanity" by George

\footnotetext{
${ }^{6}$ James E. Young, The Texture of Memory (New Haven and London: Yale University Press, 1993).

${ }^{7}$ Barbie Zelizer, ed., Visual Culture and the Holocaust (New Brunswick: Rutgers University Press, 2001).

${ }^{8}$ Marianne Hirsch, The Generation of Postmemory (New York: Columbia University Press, 2012).

${ }^{9}$ Alexandre Dauge-Roth, Writing and Filming the Genocide of the Tutsis in Rwanda (New York: Lexington Books, 2010).

${ }^{10}$ Henry Rousso, The Haunting Past: History, Memory, and Justice in Contemporary France (Philadelphia: University of Pennsylvania Press, 2002), 9.

${ }^{11}$ Jessica Fernanda Conejo Muñoz, "Memory and Distance: On Nobuhiro Suwa's A Letter from Hiroshima," Genocide Studies and Prevention 12, no. 2 (2018), 125-139.

${ }^{12}$ Examples of such advancements include increasing film speed, shortening of exposure times, massive reduction in the size and weight of cameras, and advent of social media technologies facilitating the rapid social circulation of news and imagery.

${ }^{13}$ Nicholas Mirzoeff, How to See the World (New York: Basic Books, 2016).

${ }^{14}$ It should be noted that Thomas Edison's artisanal experiments to this effect had made it technically possible to record contemporaneous sound with video since the early 1900s, though this technology was far from widespread.

${ }^{15}$ Nora Nunn, “The Unbribable Witness: Image, Word, and Testimony of Crimes against Humanity in Mark Twain's King Leopold's Soliloquy (1905)," Genocide Studies and Prevention 12, no. 2 (2018), 84-106.
} 
Washington Williams. ${ }^{16}$ To this end, the resource of the "magic lantern," a device used on a mass scale in the nineteenth century, was combined with photos taken by missionaries and accompanied with writers' accounts to denounce the atrocities committed in the Congo. Years later, photographic and film processes, especially those produced by France and Germany, dominated coverage of World War I in the form of newsreels, broadcasts and documentaries. Indeed, World War I was filmed and photographed like none other before ${ }^{17}$ even when the technical difficulties and by propagandistic intentions combined to result in re-enacted or staged situations for the cameras. ${ }^{18}$

Within the context of World War I the Armenian Genocide, widely considered the first modern genocide, took place. Deportations and resultant deaths in the Syrian Desert, in the vicinity of Aleppo, were photographically documented and resulting images were used as an instrument for denunciation as well as for raising funds by the American Committee for Armenian and Syrian Relief, created in 1915 in the United States as a humanitarian organization in response to the atrocities perpetrated against the Armenian people. Among all these visual efforts, the case of Armin T. Wegner, a German medic and solder who risked his life to capture images of massacres and deportations, stands out. In defiance of the orders of his German and Ottoman superiors, Wegner managed to take hundreds of photographs which today form the core of testimonial imagery of the Armenian Genocide. Photographs, however, were not the totality of Wegner's efforts; he also wrote notes and letters and served as a courier for the deported, taking documents to American ambassador Henry Morgenthau with a view to having them sent to the United States. As Peter Balakian notes, when one of Wegner's letters to his mother describing the atrocities was intercepted, he was expelled from the Armenian zone of the conflict and forced to work in cholera wards, where he fell gravely ill, and later was sent to Constantinople, then to Germany. Despite the risk, Wegner hid negatives of the photographs he took in his belt. ${ }^{19}$ Once the war was over, the fictional film Ravished Armenia (Oscar Apfel, 1919) was produced in support of the aforementioned American Committee for Armenian and Syrian Relief, with the objective of increasing awareness of the genocide and raising funds to aid survivors. ${ }^{20}$ Based on the memoirs of survivor Aurora Mardiganian, who was also the lead actress in the film, Ravished Armenia is widely considered the first motion picture with genocide as its main subject matter. In genealogical terms, this film can thus be described, borrowing Roland Barthes' terms to describe a style that seems to be transparent and does not draw attention on its rhetorical devices, as degree zero in the relationship between film and genocide. ${ }^{21}$

These three examples permit us to observe, from the very early stages, different aspects of visual production and use, which, far from being homogenous, embody a variety of approaches. First, the image as witness, combined with a testimonial account. Second, archival imagery as evidence, that is to say, the image as an indelible mark deemed indisputable. Third, imagery used to raise awareness, including the at-times fraudulent use of false evidence, a tactic regularly utilized by propaganda makers during the 1920s and 30s. Fourth, and finally, the recreation of imagery through staged productions, exemplified by Ravished Armenia.

These axes of production and dissemination of mass atrocity imagery continue to become increasingly elaborate. The common thread amongst these various modes of production and uses

\footnotetext{
${ }^{16}$ Adam Hochschild, King Leopold's Ghost: A Story of Greed, Terror, and Heroism in Colonial Africa (New York: Mariner Books, 1999), 112.

${ }^{17}$ Laurent Véray, La grande guerre au cinéma. De la gloire à la mémoire (Paris: Ramsay, 2008).

${ }^{18}$ Susan Sontag, Ante el dolor de los demás (Buenos Aires: Alfaguara, 2003), 29-33.

${ }^{19}$ Peter Balakian, The Burning Tigris. The Armenian Genocide and America's Response (New York: Harper Collins, 2003$), 259$. See also Sévane Garibian, "Ravished Armenia (1919) desde la mirada de Walter Benjamin. Reflexiones acerca de una película-prueba," Istor, 15, no. 62 (2015), 173-187.

${ }^{20}$ From the surviving footage of the 1919 film Ravished Armenia, Zareh and Alina Tjeknavorian made a movie called Credo in 2005. Other than the original 1919 footage, the new production introduces recorded footage of Ereván's memorial site, as well as some photographs taken by Wegner. See Donna-Lee Frieze, “Three films, one genocide: Remembering the Armenian Genocide through Ravished Armenia(s)," in Remembering Genocide, eds. Nigel Eltringham et. al. (London: Routledge, 2014), 48.

${ }^{21}$ Leshu Torchin, "To Acquaint America with Ravished Armenia," in Creating the Witness. Documenting Genocide on Film, Video, and the Internet (Minneapolis and London: University of Minnesota Press, 2012). Roland Barthes, Le degree zero de l'écriture (Paris: Seuil, 1972).
} 
of atrocity imagery is that, regardless of how it is deployed, such imagery remains a powerful tool, given it ability to select a portion of what is visible and disregard other portions, and the temporal sequence it imposes. It is also important to bear in mind the fact that the tool of visual production and documentation is not universally accessible, despite the growing ubiquity of image-capture technologies, but remains subject to conditions that require specific forms of expertise and access to equipment. As such, visual documentation must be read in conjunction with other forms of documentation which contribute to our understanding of the visual, and vice versa. Consequently, a visual document is never fully transparent, but often conceals as much, or even more, than it shows. Thus, the responsible production and consumption of atrocity imagery remains contingent on our analytic, technical, and historical abilities and competencies, as well as other such skills. Only with such abilities can such imagery effectively be made to speak in a register we can hear and understand.

\section{5: A Point of No Return}

While imagery was central to earlier events such as Dutch atrocities in the Congo, World War I and the Armenian Genocide, World War II marked an unprecedented break point in the convergence between atrocities and visual reproduction and depiction. At a time when the Holocaust was yet to be conceptualized as an independent phenomenon by the international community, Nazi atrocities, including the Holocaust, were visually documented by Allied photograph and film units when the territories occupied by the Third Reich were liberated, most notably the concentration and extermination camps, especially Soviet forces, which opened the gates of Majdanek in the summer of 1944, and then slowly advanced towards Berlin. ${ }^{22}$ Concentration camps such as Plaszow, GrossRosen, Sachsenhausen, Ravensbrück and Stutthof were visually documented, but it was not until 27 January 1945, when they arrived at Auschwitz, that the Soviets carried out their most ambitious visual documentation efforts. ${ }^{23}$

At any rate, the spring of 1945 constituted a turning point in the convergence of cameras and the horrors of World War II and the Holocaust. There was a brief period in and around April 1945 when American and British forces encountered some of the concentration camps situated in the territory previously held by the Third Reich. When American generals Dwight Eisenhower, George Patton and Omar Bradley visited the Ohrdruf camp shortly after its liberation on 5 April, they made a decision which would have significant repercussions for the visual documentation practices of atrocities to this day. They chose to visually confront the world with shocking footage filmed at the camps. Amongst those first confronted with this grisly imagery were the German people, many of whom continued to deny knowledge of the Holocaust or the camps. Germans were even brought to visit certain camps and later subjected to a barrage of newscasts and documentaries describing and often viscerally depicting the horrors committed at the camps. The Allies also routinely showed such footage to their own soldiers, in order to impress upon them why they had fought. The American War Department went so far as to produce a series of propaganda documentaries produced by their War Department, employing major Hollywood directors such as John Ford and Frank Capra. ${ }^{24}$ These early efforts were followed by an international campaign that came to be known as the "pedagogy of horror", ${ }^{25}$ and which inundated newsreels and broadcasts the world over. Such footage was also shown in judicial proceedings such as the International Military

\footnotetext{
${ }^{22}$ Ilya Ehrenburg and Vassili Grossman, Le livre noire. Textes et témoignages (Arles: Actes Sud, 1995).

${ }^{23}$ Valérie Pozner, et al., eds. Filmer la guerre 1941-1945. Les soviétiques face à la Shoah (Paris: Mémoiral de la Shoah, 2015$), 56$. See also Stuart Liebman, "El Holocausto en los juicios filmados: Swastyka i Szubienca (1945) de Kazimierz Czynski," Archivos de la Filmoteca 70 (2012).

${ }^{24}$ The propaganda series consisted of seven films under the title Why We Fight. It was conceived by general George C. Marshall in collaboration with Capra. See Clayton Koppes and Gregory Black, Hollywood Goes to War. How Politics, Profits and Propaganda Shaped World War II Movies (Berkeley \& Los Angeles: University of California Press, 1990); Thomas Doherty, Projections of War. Hollywood, American Culture, and World War II (New York: Columbia University Press, 1993).

${ }^{25}$ Marie-Anne Matard-Bonucci and Edouard Lynch eds., Le libération des camps et le retour des déportés (Brussels: Complexe, 1995).
} 
Tribunal at Nuremberg, where the Tribunal agreed to the display of audio-visual material. ${ }^{26}$ The liberation of the aforementioned camps was followed by that of Buchenwald, Dachau and later Mauthausen. Finally, the most iconic images came in the form of British photographs and filmed footage at the Bergen-Belsen camp, which was liberated on 15 April 1945.

These images and films of the horrors of the concentration camps set the horizon of expectations in 1945, yet had little to do with the totality of the processes that would later become known as the Holocaust, perpetrated in its industrial phase by means of gassing in the Nazi camps in occupied Poland and by bullet in the rear-guard of the Eastern front by the Einsatzgruppen, in its previous phase. What we are referring to currently is more of a concentration camp imaginary modeled on images, in particular those of Bergen-Belsen, as this camp was in 1945, a heteroclite and totally exceptional condensate of its previous history, and of the vicissitudes of the withdrawal of the German forces, as it had become a destination point of the death marches, and the saturation it reached was without precedent by the last days before the defeat of the Third Reich. In any case, these images helped bring about an unprecedented transformation in western visual culture. As a young girl in California, Susan Sontag was exposed to these images despite being completely unaware of their context or the intentions of those who took them and circulated them. Sontag was so shocked by them, that years later she reflected:

One's first encounter with the photographic inventory of ultimate horror is a kind of revelation, the prototypically modern revelation: a negative epiphany. For me, it was photographs of Bergen-Belsen and Dachau, which I came across by chance in a bookstore in Santa Monica in July 1945. Nothing I have seen -in photographs or in real life-ever cut me as sharply, deeply instantaneously. Indeed, it seems plausible to me to divide my life into two parts, before I saw those photographs (I was twelve) and after, though it was several years before I understood fully what they were about. What good was served by seeing them? They were only photographs -of an event I had scarcely heard of and could do nothing to affect, of suffering I could hardly imagine and could do nothing to relieve. When I looked at those photographs, something broke. Some limit had been reached, and not only that of horror; I felt irrevocably grieved, wounded, but a part of my feelings started to tighten; something went dead; something is still crying. ${ }^{27}$

\section{The Genocidal Imaginary}

The use of audio-visual images of the Holocaust and other genocide and episodes of mass violence has engendered various controversies and challenges, the disputes regarding the representation of the Holocaust being, without a doubt, in the center of the discussion. In this regard, some authors have suggested that the Holocaust is non-representable, that it escapes the competence of any language to describe it or of any medium to represent it. As George Steiner puts it: "the world of Auschwitz exists outside of words and reason." ${ }^{28}$ However, the impossibility of conceiving these events contradicts the meaningful visual material as well as the need of the victims, witnesses and liberators to document the genocide. ${ }^{29}$ Indeed, the Holocaust created a fracture in twentieth century western culture, thought, narrative, and image. For this reason, one can identify a triad of impossibilities: inconceivable, ineffable (or untellable) and non-representable. The truth is, regardless of the historical timing of its recognition as a specific and unique crime, the Holocaust radically changed the way we view the world and its representations have been paradigmatic in discussions of the limits of what is visible in any genocide.

\footnotetext{
${ }^{26}$ Christian Delage, Caught on Camera. Film in the Courtroom from the Nuremberg Trials to the Trials of the Khmer Rouge (Philadelphia: University of Pennsylvania Press, 2013) and Lawrence Douglas, The Memory of Judgment. Making Law and History in the Trials of the Holocaust (New Haven \& London: Yale University Press, 2001). Additionally, regarding the use of audiovisual material in an International Tribunal see: Iva Vukušić, "Nineteen Minutes of Horror: Insights from the Scorpions Execution Video," Genocide Studies and Prevention 12, no. 2 (2018), 35-53.

${ }^{27}$ Susan Sontag, On Photography (New York: Picador, 1973), 20

${ }^{28}$ George Steiner, Lenguaje y silencio (México: Gedisa, 1990), 166.

${ }^{29}$ Georges Didi-Huberman, Imágenes pese a todo (Barcelona: Paídós, 2005).
} 
As previously mentioned, the representation of such types of mass violence is a question that dates back to Ancient times, and which seems to have, at its core, a question that reappears time and again: is there such a thing as an adequate representation? And if so, what features should it have? Seeing as the term adequate is polysemic, these questions beget new ones: adequate in relation to reality? In relation to the experience of the victims who suffered the violence? In relation to the transmission of memory? In relation to what perspective? In regards to the Holocaust, the matrix of these reflections, some researchers have suggested that the impossibility and uniqueness is "a matter of identity politics rather than empirical findings." ${ }^{30}$ We cannot in this introduction aim to explore all the debates on the subject ${ }^{31}$ but the fact is that, as other authors point out, the Holocaust became a "metaphor or universal trope of historical trauma" ${ }^{32}$ reaching the status of being the paradigm in terms of representation of genocide. And while this has served to forge highly pertinent intellectual tools to decipher other genocides or episodes of mass violence, it also threatens to cloud some specifics of other cases if these are forced to fit into the parameters established by the Holocaust. In other words, to uphold the incomparability of the Holocaust while at the same time using it as a model can be paradoxical and paralyzing if we aspire to understand other cases. It is therefore necessary to learn from the abundant reflections on the Holocaust, but to avoid exporting a normativity to other cases, which was never the intention of the great scholars of the Holocaust.

So then, what implications stem from having the Holocaust as a representational paradigm? On one hand, this paradigm has established narratives, ways to recount the facts, which have been applied to other cases. Consequently, we find that the film Hotel Rwanda (Terry George, 2004) has been described as the black version of Schindler's List (Steven Spielberg, 1993) ${ }^{33}$ thus marginalizing any possible discussion regarding the historical figure of the main character. But above all, the Holocaust has established a "genocidal imaginary." In this way, when analyzing images of Armenian activists, Leshu Torchin finds iconographic elements similar to those of the Holocaust, stating that:

images of emaciated bodies, mounds of corpses, barbed wire and box cars - images that saturated the public, political and juridical arenas - have crystallised into a set of universalized symbols for the Holocaust, functioning as a kind of genocidal imaginary. These images provide an interpretative frame through which other genocides are produced and understood ${ }^{34}$

Rebecca Jinks also adopts this notion and, in the same vein, defines genocidal imaginary as "the mental creativeness and fluidity to envisage and conceive of a genocide (as with any historical event), but equally to emphasize that all imagination is derived from, and a composite of, the images and narratives that form the various representations of genocide circulating within the public sphere." ${ }^{35}$ But the Holocaust did not simply become a paradigm of representation in visual

\footnotetext{
${ }^{30}$ Rebecca Jinks, Representing Genocide. The Holocaust as Paradigm? (London: Bloomsbury, 2016), 6. On this question of identity, A. Dirk Moses has referred to how scholarly discourse has referred to and understood the relationship between the Holocaust and genocide as a concept and as an event. See A. Dirk Moses, "The Holocaust and Genocide," in The Historiography of the Holocaust, ed. Dan Stone (Basingstoke: Palgrave Macmillan, 2004).

${ }^{31}$ For further insight on this discussion, see Sven-Erik Rose, "Auschwitz as Hermeneutic Rupture, Differend, and Image malgré tout: Jameson, Lyotard, Didi-Huberman," in Visualizing the Holocaust. Documents, Aesthetics, Memory, ed. David Bathrick et al. (Rochester: Camden House, 2008).

${ }^{32}$ Andreas Huyssen, En busca del futuro perdido. Cultura y memoria en tiempos de globalización (Buenos Aires: Fondo de Cultura Económica, 2001), 17.

${ }^{33}$ See this discussion in Madelaine Hron, "Genres of 'Yet An Other Genocide.' Cinematic Representations of Rwanda," in Film E Genocide, ed. Kristi M. Wilson and Tomás F. Crowder-Taraborrelli (Madison: The University of Wisconsin Press, 2012), 140.

${ }^{34}$ Leshu Torchin, "Since We Forgot: Remembrance and Recognition of the Armenian Genocide in Virtual Archives," in The Image and the Witness: Trauma, Memory and Visual Culture, eds. Frances Guerin and Roger Hallas (London: Wallflower Press, 2010), 91.

${ }^{35}$ Jinks, Representing Genocide, 29.
} 
terms, it also did so in narrative and interpretative terms; thus, this paradigm established models and styles which were, bit by bit, exported to other historical cases. When, in 1979, the detention and torture center codenamed S-21 was discovered by Vietnamese soldiers after the fall of Phnom Penh, they decided to photograph and film the place following cinematographic parameters that revealed an understanding, whether direct or indirect, of panoramic and tracking shots continually used in the exhibition of the camps in 1944-1945. ${ }^{36}$ Furthermore, when the decision was made to convert the aforementioned center into a museum to denounce the atrocities perpetrated there, the Vietnamese colonel Mai Lam, who had been the man responsible for the Museum of the American War Crimes of Ho Chi Minh City, and survivor Ung Pech, who would later be named director of the Tuol Sleng Museum for Genocidal Crimes, travelled to Auschwitz, among other places, for inspiration. Both the display of certain images and, most notably, the use of victims' clothing exhibited in the cells, reflected the paradigmatic capability the Holocaust had in general, and Auschwitz in particular. ${ }^{37}$ In Argentina, the Trial of the Juntas, which took place in 1985, was called the "Argentinian Nuremberg," 38 and the clandestine detention center which functioned in the Higher School of Mechanics of the Navy (Escuela de Mecánica de la Armada) was called the "Argentinian Auschwitz." ${ }^{39}$ In Argentina, during the period of time when the prosecution of the perpetrators was banned, there was a specific popular practice of protest: the escrache. The aim was to point out the perpetrator outside their house; while the protest took place, protesters sang "they'll meet the same fate as the Nazis, wherever they go we'll come find them".

On the other hand, such dominant paradigmatic representations lock in a specific type of relationship with knowledge, that of awareness raising. We can thereby list a number of cases where audio-visual representations sparked discussions, debates and even social and political recognition. The raised awareness regarding the Holocaust has a particular relationship with television; as it was through television broadcasts that the public first started to become aware of the scope of the Holocaust, rather than the cinema. ${ }^{40}$ It was the impact of the TV miniseries Holocaust (Marvin Chomsky, 1978), which enabled Western Germany to discuss the genocide as it never had been before. ${ }^{41}$ Likewise, other films also managed to bring various cases to the public's attention, reaching audiences that no academic study had: Hotel Rwanda, The Killing Fields (Roland Joffé, 1984), La Noche de los Lá,pices (Héctor Olivera, 1986) or The Act of Killing (Joshua Oppenheimer, 2012), are all examples of such works. All of these films spurred heated debates in the public sphere, especially around the topic of their fidelity to history. The standing of these films highlights the possibilities and the status these audio-visual productions can reach. As a counterpart, films and images are not a history book, and therefore we should not ask them for what they cannot give us. ${ }^{42}$ Rather we must approach such films from the perspective of a particular methodology. In this sense, real-time images captured during the processes of genocide and mass violence can function as evidentiary documents, but we must also remain aware that imagery operates largely on the plane of sensation and emotion, opening up the possibility of imagining the past, of becoming acquainted with something, of becoming conscious of something. And in this process, images are also valuable tools to explore social imaginaries, both those of the victims and those of the perpetrators. ${ }^{43}$

\footnotetext{
${ }^{36}$ Vicente Sánchez-Biosca, “Non-Author Footage, Fertile Re-Appropriations. On Atrocity Images from Cambodia's Genocide," in A History of Cinema Without Names, ed. Diego Cavallotti et al. (Udine: Mimesis, 2015).

${ }^{37}$ David Chandler, Voices from S-21, Terror and History in Pol Pot's Secret Prison (Berkeley: University of California Press, 1999), 5-6.

${ }^{38}$ Carlos Alberto Silva, El Nüremberg Argentino (Madrid: Aura, 1986).

${ }^{39}$ Emilio Eduardo Massera and Juicio A Las Juntas, "La Esma, tierra del horror y de Massera," Clarín, November 8, 2010, accessed March 26, 2018, https://www.clarin.com/politica/ESMA-tierra-horror-Massera 0 HkSGpj56P7l.html.

${ }^{40}$ Jeffrey Shandler, While America Watches. Televising the Holocaust (New York: Oxford University Press, 1999).

${ }^{41}$ Andreas Huyssen, "La política de la identificación: 'Holocausto' y el drama en Alemania Occidental," in Después de la gran división. Modernismo, cultura de masas, posmodernismo (Buenos Aires: Adriana Hidalgo, 2002).

${ }^{42}$ Robert Rosenstone, Visions of the Past: The Challenge of Film to Our Idea of History (Cambridge, MA: Harvard University Press, 1995).

${ }^{43}$ Ana Ros, "El Mocito: A Study of Cruelty at the Intersection of Chile's Military and Civil Society," Genocide Studies and Prevention 12, no. 2 (2018), 107-124; Christophe Busch, "Bonding Images: Photography and Film as Acts of
} 


\section{Crisis of the Paradigm}

As Thomas Kuhn pointed out, paradigms can be thrown into crisis, and in this sense, the Holocaust as a paradigm also has undergone at least two crises. The first crisis concerned the very representational model of the Holocaust itself. The proliferation of images in the globalized era, as well as the generational renewal in the arts, has led to a change in strategy in its representation: from sacralization to desacralization. ${ }^{44}$ While the first style invokes authors such as Elie Wiesel or Claude Lanzmann, artists and creators using the latter strategy may conceive the representation of the Holocaust either as strategies for memory or as wider modalities of representation which do not shy away from comparing the Holocaust with other genocides, or with racial, national or biopolitical issues. In other words, within the framework of the sacral representation, we can find survivors and direct witnesses (first generation), while those who have adopted demystification strategies can be thought of as "the generation of postmemory." 45

In effect, there is also a factual element to take into account. At present, the production of images is facing (and is aimed at) generations not only born after the Holocaust, but who also do not have direct ties with survivors or witnesses of Nazism. Therefore, the representation models that came into play for those contemporary to the events might not be the most adequate, or might not work the same way, for their successors.

The crisis of the paradigm also had a historical/political side. On the one hand, history has shown that mass atrocities such as the Holocaust have occurred repeatedly in the post-World War II era and therefore, the phenomena of mass violence and extermination efforts turned out to be not so unique or even exceptional, but rather a specific way to resolve political disputes. On the other hand, the "lessons of the Holocaust", that is, universal lessons taken from that case which were supposed to aid in the prevention of genocides, ${ }^{46}$ entered into crisis mode when they became ineffective in the face of the Rwandan genocide against the Tutsi, or the Srebrenica genocide, to mention but two examples.

As such, these crises permit us to bring into question the current status of the Holocaust as an effective representation paradigm. In this sense, and borrowing from the debates regarding the adequate modes of representation, we argue that talking about strategies of representation is a valid option. In this way, rather than consider a single or imperative representation model, representation strategies have exploded in a variety of complex models and formats. As the articles of this special issue will elaborate on, representations continue to be produced in their traditional formats, such as photography and film, but have also expanded to other formats as well, such as the performing arts, ${ }^{47}$ animation, ${ }^{48}$ and graphic novels ${ }^{49}$ among others.

\section{The Power and Limits of Images}

"Photographs attract false beliefs the way flypaper attracts flies," wrote Errol Morris in a provocative study on the photographs of events at the Abu Ghraib prison which shook public opinion in 2004..$^{50}$ The American filmmaker pronounced these paradoxical words in response to the alleged evidence of snapshots that the American media published in the spring of 2004 and which depicted practices of humiliation and physical violence perpetrated by Military Police representatives on Iraqi prisoners, all of them captured by the very perpetrators of said acts during

Perpetration," Genocide Studies and Prevention 12, no. 2 (2018), 54-83.

${ }^{44}$ Dora Apel, Memory Effects. The Holocaust and the Art of Secondary Witnessing (New Brunswick: Rutgers University Press, 2002).

${ }^{45}$ Hirsch, The Generation of Postmemory.

${ }^{46}$ Peter Novick, The Holocaust in American Life (Boston: Mariner, 1999).

${ }^{47}$ Lacey Schauwecker, "'You Could See Rage:' Visual Testimony in Post-Genocide Guatemala," Genocide Studies and Prevention 12, no. 2 (2018), 18-34.

${ }^{48}$ Vicente Sánchez-Biosca, "Challenging Old and New Images Representing the Cambodian Genocide: The Missing Picture (Rithy Panh, 2013)," Genocide Studies and Prevention 12, no. 2 (2018), 140-164.

${ }^{49}$ Deborah Mayersen, "Cockroaches, Cows and 'Canines of the Hebrew Faith:' Exploring Animal Imagery in Graphic Novels about Genocide," Genocide Studies and Prevention 12, no. 2 (2018), 165-178.

${ }^{50}$ Errol Morris, Believing is Seeing. Observations on the Mysteries of Photography (New York: Penguin Press, 2011), 92. 
the previous autumn. The immediate reaction of the intellectual community and, subsequently, the international community, went beyond mere accusations against the Bush administration in regards to their contempt for the administration's self-described "war on terror" and the various human rights violations committed as part of it. They did something else as well. Seymour M. Hersh expressed it with candor in the pages of The New Yorker: "The photographs tell it all." ${ }^{51}$ The thing that Errol Morris' book, as well as his film Standard Operating Procedure (2008), highlighted, however, was something very different: that the pictures of those individuals posing with a sense of triumph in front of the abased bodies of prisoners were concealing the reality of what had happened as much as they showed it. In other words, while they elicited mass repudiation for the obscenity of the perpetrators objectifying their prisoners to make them puppets in their sexual fantasies, and objects of their perversions and scorn, this did not mean that their content provided the reality of what went on inside the walls of the prison.

Let us take a brief look into a single case: the infamously obscene photograph of Sabrina Harman posing with her thumb up by the plastic-wrapped body of a prisoner named Al-Jamadi. In said picture, Harman's smile displayed a sort of mix between the traditional trophy picture and the selfie - avant la lettre. However, this piece of evidence, which was used against her in court, conceals a more relevant fact: that the prisoner had not been tortured by this woman nor by any of her companions who took the photograph. Historical investigation revealed that the perpetrators were members of the Military Intelligence, who form the true elite of interrogations and torture. Thus, Sabrina and her colleagues from the Military Police were tasked with the cleaning duty and wiped the traces of torture from the body so as to make the murderers unidentifiable. In light of this, whatever their accountability and complicity, the clear evidence of the photograph as it was presented by the press turns out to be equivocal, as it conceals, in effect, the real killer at the same time that it generates a reaction of such outraged condemnation in the public that it deters them from wondering about what could be behind the photograph.

The Abu Ghraib photos are a good example to introduce a question that we consider crucial in regards to the mechanisms and resources of photographic representation and, by extension, of all images, at least those captured directly from reality ${ }^{52}$ The photograph's first condition is that it is the representation of something, that is to say that while the mechanic and digital media conserve a stringent trace of reality (what in linguistic terms and according to American pragmatist Charles Sanders Pierce we call its indexical status), ${ }^{53}$ the other elements that come together to compose the photograph answer to codes of the device which are subject to manipulation by means of technical-linguistic procedures and which, in any case, are anything but natural: setting the frame in accordance with the possible formats of the device, decisions on the composition of the forms within the frame, selecting the viewpoint, use of the depth of field, among others. Whether these decisions are made consciously and deliberately or, conversely, at random and determined by the conditions they were taken in, does not change in the slightest its status as codified, but it is pertinent when it comes to understanding the circumstances operating at the time the scenes were captured, as any images captured during an instance of violence are often accompanied by danger, tension and a transience of the details. Consequently, the first precaution an interpreter of such images should take is to be suspicious of their transparency, that is, they should eschew the prospect of reading them as an accurate reflection of a pre-existing reality that is reproduced and wholly incarnated in the resulting visual product. To challenge this notion means to bring to the foreground the need for specific competences for the study of images; skills that are partly technical and partly semiotic (that is, relating to the production of meaning).

In short, the production of an image is the result, in the first place, of the transformation of one particular gaze through the options offered by a technical stylistic device; in the second place, of the compromise between the intent of an author and the pragmatic conditions of the shot. When capturing a scene of violence, the author of the image selects a position from those that are open

\footnotetext{
${ }^{51}$ Seymour M. Hersh, "Torture at Abu Ghraib," The New Yorker, May 10, 2004.

${ }^{52}$ Another classic author will posit that photography carries its referent within itself, see: Roland Barthes, La cámara lúcida. Nota sobre la fotografía (Barcelona: Gustavo Gili, 1982), 33.

${ }^{53}$ Philippe Dubois, L'acte photographique (Paris \& Bruxelles: Nathan \& Labor, 1983), 49.
} 
to them given the conditions of urgency/emergency the scene is taking place in, but also according to the role they play in the course of the scene. We call this the image modality, namely: a set of factors which entail a physical point of view but which also imply a perspective towards the action, and which can, ultimately, reveal a moral or political stance on the facts. ${ }^{54}$ Hence why it is justified to speak of at least three distinct modalities which establish, in semiotic terms, the relationship between the subject and the object of the representation: images by the perpetrators, images by liberators, and images by direct witnesses. The first category is composed of the ones taken by those inflicting the violence or by their accomplices, at the time (or around the time) of the violence. The second category, such as the aforementioned ones concerning the liberation of the concentration camps in the spring of 1945, or those taken by the Vietnamese in January 1979 in Phnom Penh, comprises the images captured by those who, having missed the violence as it was taking place, represent it through a metonymic procedure, namely, displaying its effects or consequences. Given the limitations these will face from the start, there will be a natural tendency to mitigate that deficiency through an excess in results or, in other words, the more violent the evidence in these images, the more effective and damning they will appear to be. However, we must not forget the hiatus that mediates between the infliction of violence (invisible and past) and the moment its effects are captured. Therefore, it becomes necessary to take into consideration the errors, deceptions, simulations or staged scenes that could have been produced, deliberately or not, between both instants, and regardless of any intent of its authors to be realistic. Finally, the images by witnesses, most of which are taken by photojournalists from the press, newsreels or television, whose physical proximity, respect or lack thereof by the perpetrators and knowledge of the factors which remain outside the sphere of representation of the images can vary greatly. Given the proliferation of visual devices in our time, it is becoming increasingly frequent for these images to be registered by non-professional devices, to the point that it will be difficult in the future to conceive of acts of violence without a visual record of the events.

In all three of the modalities listed, historians of genocide must be aware that the resulting image is an emanation, a remnant and a part of a bigger event and that their interpretative work of the event must be coupled with a deciphering of codes, as well as determining, insofar as it is possible, everything that remained outside of the shot which, rather than being lost forever, could be deduced or revealed, whether through a thorough examination of the internal elements of the image itself (projected shadows, body fragments, gazes directed off-screen, signs of surprise, terror, dismay, threats, et cetera) or through other images captured from different angles. Assembling these puzzles (which in analog photography stemmed from something so elemental, and so eloquent, as identifying the original negative film and comparing it with the pictures circulated) constitutes a specific and inalienable task of those trained in this type of image analysis. Let us look briefly at three examples.

One instance of images created by atrocity perpetrators is the nineteen-minute long video taken by the Serbian Scorpions squad after the fall of Srebrenica, which constitutes the body of research of Iva Vukušićs text. What information does this video provide us with that could not have been obtained through other sources, as the author establishes? First, the relationship between the victim and the perpetrator in the instants before the crime. Second, the physical conditions in which the crimes took place (humiliation of the victims, physicality, etc.), as well as the intention of committing the crime. Third, the duration of the events. Fourth, the exact words pronounced coupled with the language used (the tone, the imprecation, the accent). Fifth and finally, the link between the perpetrators themselves, the team spirit that bonded them together in the perpetration of the crimes depicted. To this list should be added the communal transmission, the spirit of belonging to the point that these images by the perpetrators become a kind of site of memory, discreet, intimate, and hidden to outsiders until there was a leak.

\footnotetext{
${ }^{54}$ Narratology studies formalized concepts such as "ocularization" to refer to the adoption of the physical position of a subject relating to its surroundings, distinguishing it from other concepts such as focalization (which has a function of knowledge in relation to the narrative). See François Jost, L'œil-caméra. Entre film et roman (Lyon: Presses Universitaires de Lyon, 1987). Evidently, this is not the place to delve into such complex matters, but we must note that these notions can be recovered to apply to documentary material in order to enlighten our subject matter.
} 
We will not expand on the images by the liberators since we have already discussed their mechanisms in relation to the discovery of the camps in the spring of 1945. Yet let us linger for a second in the third modality. On Monday 11 April 1994, at around 10 in the morning, reporter Nick Hughes captured some horrifying images of a killing on a road in Kigali from the top floor of a building known as the French school. ${ }^{55}$ His video is interrupted at several points as he captures the strange normalcy, periodically punctuated by extreme manifestations of violence when several Rwandan Tutsi victims are executed with machetes. The difficulty to see clearly is determined by a combination of a series of technical constraints and stylistic options, namely: the vast distance separating the camera from the violent acts hinders the identification of the victims and the perpetrators of the actions. This distance is a product of the danger presented by such documentation, as if Hughes moved closer, he would increase the risk to his own life. However, Hughes pushes his camera device to its limits in relation to its telephoto lens usage: the telephoto lens naturally flattens the image and produces a lot of instability in the take. Therefore, the conditions in which the images were captured have left perceptible marks in the recording of the film, and deciphering these marks will provide us with clues to understand what happened, always in conjunction with other complementary sources of information, of course. On the other hand, the camera was unable to capture the sounds, screams and begging of the perpetrators and the victims of the massacre, so the video only picks up children's voices and the reactions of fear and terror of the people close to the camera. These comprise some of the very few images we have of the Rwandan genocide. And they represent the modality of images taken by witnesses. As follows from this brief description, the analysis of such images will also provide us with clues to evaluate the quality of the resulting document (its deficiencies, the straining of the device's capabilities, the asynchrony between sound and image, the disruptions due to the shortage of tape and battery power, etc.).

\section{Circulation and Narrative}

The images that crystallize the genocides and violence do not stop circulating, both in a synchronic sense, that is to say, through the media (from photography to the press, from the newscast to the documentary or social media) and in a diachronic or historical sense, in that they are repurposed by later films in order to conjure those moments they are associated with, as well as to actualize, modify or even subvert their original meaning. ${ }^{56}$ This circulation of images is crucial for the cases in question, precisely because of the dearth of available visual evidence in relation to many such episodes of violence. In other words, the more sparse these images are, the more frequent their use to evoke the events swiftly and, furthermore, the more varied the meanings ascribed to said images become within new narrative contexts, such as fiction and documentary, imitation and rewriting, altering meaning, et cetera. Truth be told, the changes in perspective in the study of genocide and mass violence could even be studied in relation to the rewritings these images are subject to. For example, the video footage of the Jewish ghetto in Warsaw, produced by a Propaganda Kompanie of Joseph Goebbels' Ministry of Public Enlightenment and Propaganda in the May 1942, was later utilized to denounce Nazism after being discovered rolled up in coils and abandoned in German archives. Erwin Leiser, Frédéric Rossif, and Yael Hersonski, among many others, would use them in very different settings, displaying at once stylistic tendencies and period-typical narratives which were very disparate: editing, conventional documentaries, testimonial context, archive era, and so forth. ${ }^{57}$ And to merely touch upon this circulation in the field of photography, it is worth mentioning how an image of the Holocaust has survived, transformed, for decades until it became one of the symbols of human suffering. The famous photograph included in the Stroop Report titled Es Gibt Keinen Jüdischen Wohnbezirk in Warschau Mehr! (The Jewish Quarter of Warsaw Is No

\footnotetext{
${ }^{55}$ Vicente Sánchez-Biosca, Miradas criminales, ojos de víctima. Imágenes de la aflicción en Camboya (Buenos Aires: Prometeo, 2017), 31-36.

${ }^{56}$ Alice Cati and Vicente Sánchez-Biosca, “Questioning Images of Atrocity: An Introduction”, Cinéma \& Cie 15, no. 24 (2015).

${ }^{57}$ Vicente Sánchez-Biosca, “Disparos en el ghetto. En torno a la migración de las imágenes de archive," Secuencias 35 (2012). The archive era has been treated comprehensively in Jaimie Baron, Archive Effect: Found Footage and the Audiovisual Experience of History (New York: Routledge, 2014).
} 
More), which shows a child with his arms raised, slightly apart from a group of Jewish people who are abandoning a household with their bags. ${ }^{58}$ The uses of said photograph within and outside the scope of the Holocaust have been innumerable, and many books have been dedicated precisely to its study..$^{59}$

The preceding considerations regarding the modalities of the image, that is, the determination of the position (both physical and, partly, ethical) of the one capturing the image in relation to the acts represented in it, and to the circulation of the image, are only part of the problem. Whether we are referring to the snapshot of a photograph or to a more prolonged time frame, as is the case with film footage and video, a narrative dimension is almost necessarily superimposed on atrocity imagery. Fragmented or meticulously built, limited to a series of actions hastily put together, or subject to the structure of a written script, both in the realm of documentaries and in the format of fiction, the dimension of narrative is always invoked by the image. And given the specific context of genocide and mass violence, such narratives tend to perform an explanatory function, by which we mean the identification of a cause and effect of the actions and the articulation of the interactions between characters, real and fictitious. In this last case, genre framing is crucial, along with the emotional expectations inherent to film codes. Thus, melodrama, the different subgenres of drama, thrillers, art films, TV series, or even the Hollywood blockbusters managed to crystallize an iconography and spectacular narrative form. The aforementioned examples of Schindler's List, The Killing Fields and Hotel Rwanda are quite eloquent regarding three of the genocides from the twentieth century.

\section{Historicity of the Facts and Historicity of the Image}

Images of the past always pose a dialectic that is difficult to analyze between the consideration to its production coordinates and the adaptation of its historical marks to the present. This aspect is, so to speak, the other side of the coin of the historicity of the image. According to Sylvie Lindeperg, images possess a historicity that is inscribed in them in ways sometimes near invisible to the uninitiated (markings in the film, format $-35 \mathrm{~mm}, 16 \mathrm{~mm}, 9.6 \mathrm{~mm}, 8 \mathrm{~mm}$ or Super 8 , among others; soundtrack; photographic cameras $-6 \times 6 \mathrm{~mm}, 35 \mathrm{~mm}$; etc.). ${ }^{60}$ In consequence, the images filmed capture that which remains imperceptible in a time period, the part of the event that is unintelligible for its contemporaries, and such images retain that which has eluded the gaze of the cameraman in his mechanical record of a portion of reality. These "fuites de sens" (Lindeperg invokes this term in the sense that it was used by historian Carlo Ginzburg) are expressed by means of discreet elements present in the shot. ${ }^{61}$ Conversely, the visit to the past through its images in our time happens through an adaptation of the formats of the past to the consumption norms and interpretative habits of the present day. Thus, for example, images are digitally colorized, adapted to a surround sound system or, in a less perceptible way, 4:3 formats are converted to $16: 9$ for the purpose of making them more legible. In all of these cases, the consumption of images of the past, including those linked to history tourism, ${ }^{62}$ goes hand in hand with an adaptation, and therefore with the erasure of the historicity of the image; an error that any historian would condemn without reserve if it pertained to written documents, for which there exists a long and substantial tradition of exegesis and textual critique. This defect constitutes the worst blunder a historian can commit: anachronism, a form of presentism. Nevertheless, this perversion of history, scandalous for anyone trained in this field, continues to be all too common in the present with barely a few protests voiced.

This is, then, the challenge this special issue faces. Genocide Studies and Prevention: An International Journal, aims to take images seriously as carriers of historicity, both in the technical and formal sense, from the question of who captures a scene of violence and how they view it, what their

\footnotetext{
${ }^{58}$ Jürgen Stroop, The Stroop Report. A Facsimile edition and translation of the official Nazi Report on the Destruction of the Warsaw Ghetto (New York: Pantheon Books, 1979).

${ }^{59}$ Frédéric Rousseau, L'Enfant juif de Varsovie: Histoire d'une photographie (Paris: Seuil, 2009).

${ }^{60}$ Sylvie Lindeperg, La voie des images. Quatre histoires de tournage au printemps-été 1944 (París: Verdier, 2013).

${ }^{61}$ Ibid., 11.

${ }^{62}$ Marita Sturken, Tourists of History: Memory, Kitsch, and Consumerism from Oklahoma City to Ground Zero (Durham: Duke University Press, 2007).
} 
spatial and temporal conditions were in relation to the events, their degree of involvement, to the way in which the narrative acts as a form of interpretation, that is to say, as a way to establish cause and effect relationships that produce explanations that recognize a single cause for phenomena that tend to be heavily over determined. Thus, to ponder images representing genocide and atrocity does not consist of viewing such images as transparent pieces of data, as unmarked instruments, but rather to observe them as historical products of multiple levels. In accordance with their origin and the context they were produced in. In terms of their circulation, normative capacity and heritage. How they are adapted in other directions, and so on. To interpret images of genocide consequently means to possess a double competence, which puts genocide specialists (historians, anthropologists, sociologists, psychologists, among others) and image analysts (semiologists, film or photography historians, new media specialists) in a separately fragile situation. There are at once, multiple fields of expertise demanded by the task, as well as specialized instruments for analysis necessary to make the best out of efforts to read and scrutinize such visual texts. The question continues to be: what can the image contribute -as iconography and as a narrative- to the comprehension of genocide and mass violence that could not be gained from any of the other documents available, but the interpretation of which requires the comprehension, study and consideration undertaken by history as a discipline? This is a delicate question, and therefore its answers must be both ambitious and open to discussion and contestation. This is the challenge we have undertaken as editors of this special issue. We believe that the eight articles that make up this publication are concrete answers to aspects of the questions raised in this introduction,, all of them significant to the study of genocide.

\section{The Articles in this Special Issue}

The special issue begins with the aforementioned text by Iva Vukušić, Nineteen Minutes of Horror: Insights from the Scorpions Execution Video. The Scorpions unit, dispatched to support the Bosnian Serb Army participated in the Srebrenica genocide in the summer of 1995 and a member of the unit filmed some of their executions. Fragments of the video were first shown during the Slobodan Milosevic trial, and multiple times in the years after, in the courtrooms in The Hague and Belgrade. The author notes that the video provides unique insights into the nature of the crime, as well as the behavior of the perpetrators, and it constitutes a significant contribution to our knowledge of the events at Srebrenica, and concerning how individuals are held accountable for mass atrocity crimes.

Christophe Busch's article focuses on the photographs taken by the Nazis so as to study the images taken by perpetrators. In this way, the author analyses how photography is utilized to create an in-group (an us opposed to a them), noting that, as images are performative, the imagery bound the in-group (us) in processes of perpetration of violence and bound the out-group (them) in processes of victimization. In consequence, Busch argues that capturing and presenting the incremental stages of "otherization" through photographic imagery contributed to the intense bond of perpetration and victimization for each respective group separately.

The figure of the perpetrator is also analyzed by Ana Laura Ros in her analysis of the documentary film El Mocito: A Study of Cruelty at the Intersection of Chile's Military and Civil Society (Marcela Said and Jacques de Certau, 2011). El Mocito tackles Chile's dictatorial past through the perspective of a civilian who was closely connected to the Armed Forces. It addresses the case of an individual living on the border between worlds often perceived as mutually exclusive (i.e. the victim and the perpetrator of atrocity). He is a civilian, but he was also a member of the DINAChile's secret police under Pinochet- though not as a member of the Armed Forces, but rather in the role of a butler. The author posits that the film poses questions about responsibility for, and complicity with, the cruelty that took place during the military regime and beyond, which all members of Chilean society must consider.

In Vicente Sánchez-Biosca's article, Challenging Old and New Images Representing the Cambodian Genocide: 'The Missing Picture', the author examines the film L'image Manquante (Rithy Panh, 2013) to highlight the way in which the French-schooled Cambodian director approaches the classical question inherited from the Holocaust of the non-representability of a genocide, applying it this time to a different case- the one perpetrated by the Khmer Rouge- under very different conditions. 
Rithy Panh starts with an analysis of the few archival images which have been used to evoke the violence of Pol Pot's regime in all its variants and, perceiving them to be insufficient, he sets in motion an original procedure: he manifests his memories through clay figures which, once sculpted and painted, would be placed on a diorama to represent lived experiences of the protagonist.

In "You Could See Rage": Visual Testimony in Post-genocide Guatemala, Lacey M. Schauwecker analyses the link between narrative and audio-visual testimonies to study the Guatemalan genocide. Using the notions of visuality and countervisuality, the author analyses the visual testimony as that which acknowledges the dynamic interplay between word and image, as well as various power relations. In this context, she examines how survivor Rigoberta Menchú and performance artist Regina José Galindo utilize this type of testimony to express rage. Thereby, the author associates this type of testimony with the witnesses' right to testify on their own terms beyond institutional processes and imperatives.

In Cockroaches, Cows and "Canines of the Hebrew Faith": Exploring Animal Imagery in Graphic Novels about Genocide, Deborah Mayersen suggests that graphic novels about genocide feature a surprisingly rich array of animal imagery. While there has been substantial analysis of the anthropomorphic animals in Maus, Mayersen argues that the roles and functions of non-anthropomorphized animals have received scant attention. In this vein, in her article she carries out a comparative analysis of ten graphic novels about genocide to identify and elucidate the archetypical functions of nonanthropomorphized animals. She posits then that animal imagery can be a powerful technique for creating an affective context, communicating both simple and complex emotions in an effective way and this could explain the prevalence of animal imagery in graphic novels about genocide.

Nora Nunn's article, The Unbribable Witness: Image, Word, and Testimony of Crimes against Humanity in Mark Twain's King Leopold's Soliloquy (1905), studies the crimes committed in the Belgian Congo Free State through the work of Mark Twain. The author suggests that this text aimed to evoke its Euro-American audience's empathy by activating their imaginations. In this way, Nunn considers how the visual imagery in Twain's text engenders questions about fact, testimony, and witnessing in the realm of human rights and mass violence -both in the Congo Free State and, indirectly, in the United States. Nunn suggests that the relation of visual imagery to written text in this relatively unknown and understudied work by Twain yields vital implications for scholars of genocide.

In her article Memory and Distance: On Nobuhiro Suwa's A Letter from Hiroshima, Jessica Fernanda Conejo Muñoz analyses said 2002 short film from the aforementioned Japanese director. This short film allows the author to examine various memory strategies regarding the atomic bombing in the Japanese city referenced in the title. Conejo Muñoz argues that this short film is a reflective game whose approach to the past is based on distancing effects. The distanciation effect, understood in the sense of Bertolt Brecht's theatrical strategies and counter cinema, is part of an experimental process that becomes a political technique of construction and decipherment of memory. Suwa's work is opposed to the belief that history is something that can be narrated, since the process of addressing the past is not carried out through a causal story, but by the principles of intransitivity, estrangement and narrative aperture.

With the different articles included in this special issue, we aim at offering the reader an overview on the various perspectives from which contemporary disciplines address the visual aspect of genocide and mass violence and contemporary artistic and media discourses represent them. Whatever these perspectives might be, and beyond the absence of definitive answers, the analysis must not be carried out in the absence of one specific competence: the analysis of the visual resources through which the infamous event is represented. These cases extracted from different geographical and historical contexts are but samples of a variety of visual modes and supports to the challenge of how to represent a genocide.

\section{Acknowledgements}

This introduction was translated by Lucía Tejada. 
Bibliography

Apel, Dora. Memory Effects. The Holocaust and the Art of Secondary Witnessing. New Brunswick: Rutgers University Press, 2002.

Balakian, Peter. The Burning Tigris. The Armenian Genocide and America's Response. New York: Harper Collins, 2003.

Baron, Jaimie. Archive Effect: Found Footage and the Audiovisual Experience of History. New York: Routledge, 2014.

Barthes, Roland. Le degré zéro de l'écriture. Paris: Seuil, 1972.

-------. La cámara lúcida. Nota sobre la fotografía. Barcelona: Gustavo Gili, 1982.

Burucúa, José Emilio and Nicolás Kwiatkowski. "Cómo sucedieron estas cosas." Representar masacres y genocidios. Buenos Aires: Katz, 2014.

Busch, Christophe. "Bonding Images: Photography and Film as Acts of Perpetration." Genocide Studies and Prevention 12, no. 2 (2018), 54-83. https://doi.org/10.5038/1911-9933.12.2.1526

Cati, Alice and Vicente Sánchez-Biosca, "Questioning Images of Atrocity: An Introduction." Cinéma $\mathcal{E}$ Cie 15, no. 24 (2015), 9-16.

Chandler, David. Voices from S-21, Terror and History in Pol Pot's Secret Prison. Berkeley: University of California Press, 1999.

Conejo Muñoz, Jessica Fernanda. "Memory and Distance: On Nobuhiro Suwa's A Letter from Hiroshima." Genocide Studies and Prevention 12, no. 2 (2018), 125-139. https://doi.org/10.5038/1911-9933.12.2.1520

Dauge-Roth, Alexandre. Writing and Filming the Genocide of the Tutsis in Rwanda. New York: Lexington Books, 2010.

Didi-Huberman, Georges. Imágenes pese a todo. Barcelona: Paídós, 2005.

Doherty, Thomas. Projections of War. Hollywood, American Culture, and World War II. New York: Columbia University Press, 1993.

Douglas, Lawrence. The Memory of Judgment. Making Law and History in the Trials of the Holocaust. New Haven and London: Yale University Press, 2001.

Dubois, Philippe. L'acte photographique. Paris and Bruxelles: Nathan \& Labor, 1983.

Ehrenburg, Ilya and Vassili Grossman, Le livre noire. Textes et témoignages. Arles: Actes Sud, 1995.

Frieze, Donna-Lee. "Three films, one genocide: Remembering the Armenian Genocide through Ravished Armenia(s)." In Remembering Genocide, edited by Nigel Eltringham and Pam Maclean, 38-53. London: Routledge, 2014.

Garibian, Sévane. "Ravished Armenia (1919) desde la mirada de Walter Benjamin. Reflexiones acerca de una película-prueba." Istor, 15, no. 62 (2015), 173-187.

Hersh, Seymour M. “Torture at Abu Ghraib." The New Yorker, May 10, 2004.

Hirsch, Marianne. The Generation of Postmemory. New York: Columbia University Press, 2012.

Hochschild, Adam. King Leopold's Ghost: A Story of Greed, Terror, and Heroism in Colonial Africa. New York: Mariner Books, 1999.

Hron, Madelaine. "Genres of 'Yet An Other Genocide.' Cinematic Representations of Rwanda." In Film E Genocide, edited by Kristi M. Wilson and Tomás F. Crowder-Taraborrelli, 133-153. Madison: The University of Wisconsin Press, 2012.

Huyssen, Andreas. "La política de la identificación: 'Holocausto' y el drama en Alemania Occidental." In Después de la gran división. Modernismo, cultura de masas, posmodernismo, 170-203. Buenos Aires: Adriana Hidalgo, 2002.

Huyssen, Andreas. En busca del futuro perdido. Cultura y memoria en tiempos de globalización. Buenos Aires: Fondo de Cultura Económica, 2001.

Jinks, Rebecca. Representing Genocide. The Holocaust as Paradigm? London: Bloomsbury, 2016.

Jost, François. L'œil-caméra. Entre film et roman. Lyon: Presses Universitaires de Lyon, 1987.

Koppes, Clayton and Gregory Black. Hollywood Goes to War. How Politics, Profits and Propaganda Shaped World War II Movies. Berkeley \& Los Angeles: University of California Press, 1990.

Kuper, Leo. Genocide: Its Political Use in the Twentieth Century. New Haven and London: Yale University Press, 1981.

Liebman, Stuart. "El Holocausto en los juicios filmados: Swastyka i Szubienca (1945) de Kazimierz Czynski." Archivos de la Filmoteca 70 (2012), 15-27. 
Lindeperg, Sylvie. La voie des images. Quatre histoires de tournage au printemps-été 1944. París: Verdier, 2013.

Massera, Emilio Eduardo and Juicio A Las Juntas. "La Esma, tierra del horror y de Massera." Clarín, November 8, 2010. Accessed March 26, 2018. https://www.clarin.com/politica/ ESMA-tierra-horror-Massera 0 HkSGpj56P7l.html.

Matard-Bonucci, Marie-Anne and Edouard Lynch eds. Le libération des camps et le retour des déportés. Brussels: Complexe, 1995.

Mayersen, Deborah. “Cockroaches, Cows and 'Canines of the Hebrew Faith:' Exploring Animal Imagery in Graphic Novels about Genocide." Genocide Studies and Prevention 12, no. 2 (2018), 165-178. https://doi.org/10.5038/1911-9933.12.2.1486

Mirzoeff, Nicholas. How to See the World. New York: Basic Books, 2016.

Mitchell, W. J. T. Teoría de la imagen. Madrid: Akal, 2009.

Morris, Errol. Believing is Seeing. Observations on the Mysteries of Photography. New York: Penguin Press, 2011.

Moses, A. Dirk. "The Holocaust and Genocide." In The Historiography of the Holocaust, edited by Dan Stone, 533-555. Basingstoke: Palgrave Macmillan, 2004

Nora, Pierre. Pierre Nora en Les lieux de mémoire. Montevideo: Trilce, 2008.

Novick, Peter. The Holocaust in American Life. Boston: Mariner, 1999.

Nunn, Nora. "The Unbribable Witness: Image, Word, and Testimony of Crimes against Humanity in Mark Twain's King Leopold's Soliloquy (1905)." Genocide Studies and Prevention 12, no. 2 (2018), 84-106. https://doi.org/10.5038/1911-9933.12.2.1525

Ros, Ana. "El Mocito: A Study of Cruelty at the Intersection of Chile's Military and Civil Society." Genocide Studies and Prevention 12, no. 2 (2018), 107-124. https://doi.org/10.5038/19119933.12.2.1524

Rose, Sven-Erik. "Auschwitz as Hermeneutic Rupture, Differend, and Image malgré tout: Jameson, Lyotard, Didi-Huberman." In Visualizing the Holocaust. Documents, Aesthetics, Memory, edited by David Bathrick, Brad Prager, and Michael Richardson, 114-137. Rochester: Camden House, 2008.

Rosenstone, Robert. Visions of the Past: The Challenge of Film to Our Idea of History. Cambridge, MA: Harvard University Press, 1995.

Rousseau, Frédéric. L'Enfant juif de Varsovie: Histoire d'une photographie. Paris: Seuil, 2009. Rousso, Henry. The Haunting Past: History, Memory, and Justice in Contemporary France. Philadelphia: University of Pennsylvania Press, 2002.

Sánchez-Biosca, Vincente. "Challenging Old and New Images Representing the Cambodian Genocide: The Missing Picture (Rithy Panh, 2013)." Genocide Studies and Prevention 12, no. 2 (2018), 140-164. https://doi.org/10.5038/1911-9933.12.2.1508

. "Disparos en el ghetto. En torno a la migración de las imágenes de archive." Secuencias 35 (2012), 31-58.

. "Non-Author Footage, Fertile Re-Appropriations. On Atrocity Images from Cambodia's Genocide." In A History of Cinema Without Names, edited by Diego Cavallotti, Simone Dotto, and Leonardo Quaresima, 137-145. Udine: Mimesis, 2015.

-------. Miradas criminales, ojos de víctima. Imágenes de la aflicción en Camboya. Buenos Aires: Prometeo, 2017.

Schauwecker, Lacey. "'You Could See Rage:' Visual Testimony in Post-Genocide Guatemala." Genocide Studies and Prevention 12, no. 2 (2018), 18-34. https://doi.org/10.5038/19119933.12.2.1529

Shandler, Jeffrey. While America Watches. Televising the Holocaust. New York: Oxford University Press, 1999.

Silva, Carlos Alberto. El Nüremberg Argentino. Madrid: Aura, 1986.

Sontag, Susan. Ante el dolor de los demás. Buenos Aires: Alfaguara, 2003.

-------. On Photography. New York: Picador, 1973.

Steiner, George. Lenguaje y silencio. México: Gedisa, 1990.

Stroop, Jürgen. The Stroop Report. A Facsimile edition and translation of the official Nazi Report on the Destruction of the Warsaw Ghetto. New York: Pantheon Books, 1979. 
Sturken, Marita. Tourists of History: Memory, Kitsch, and Consumerism from Oklahoma City to Ground Zero. Durham: Duke University Press, 2007. https://doi.org/10.1215/9780822390510

Torchin, Leshu. "Since We Forgot: Remembrance and Recognition of the Armenian Genocide in Virtual Archives." In The Image and the Witness: Trauma, Memory and Visual Culture, edited by Frances Guerin and Roger Hallas, 82-97. London: Wallflower Press, 2010.

---------. "To Acquaint America with Ravished Armenia", in Creating the Witness. Documenting Genocide on Film, Video, and the Internet, 21-60. Minneapolis and London: University of Minnesota Press, 2012.

Véray, Laurent. La grande guerre au cinéma. De la gloire à la mémoire. Paris: Ramsay, 2008.

Vukušić, Iva. "Nineteen Minutes of Horror: Insights from the Scorpions Execution Video." Genocide Studies and Prevention 12, no. 2 (2018), 35-53. https://doi.org/10.5038/1911-9933.12.2.1527

Young, James E. The Texture of Memory. New Haven and London: Yale University Press, 1993.

Zelizer, Barbie, ed. Visual Culture and the Holocaust. New Brunswick: Rutgers University Press, 2001. 